PAEDAGOGIA ChristianA

$1 / 23(2009)$ - ISSN 1505-6872

Joanna Cukras-Stelagowska*

Toruń

\title{
Od chederu do jesziwy w polskiej diasporze... - dwustopniowy system żydowskiego szkolnictwa religijnego i jego współczesne transformacje
}

Idee pielęgnowania tożsamości mniejszości narodowych oraz upowszechniania dialogu międzykulturowego na trwałe wpisały się do refleksji pedagogicznej. Masowe migracje, powstanie wspólnot ponadnarodowych, obserwowalny wzrost aktywności mniejszości kulturowych, kwestionowanie dominującego centrum, jednym słowem przejście od monolitu do polifoniczności świata społecznego, pozwala dziś na głośne mówienie o wielokulturowości - tzn. o „współwystępowaniu na tej samej przestrzeni (albo w bezpośrednim sąsiedztwie bez wyraźnego rozgraniczenia, albo w sytuacji aspiracji do zajęcia tej samej przestrzeni) dwóch lub więcej grup społecznych o odmiennych cechach dystynktywnych: wyglądzie zewnętrznym, języku, wyznaniu religijnym, układzie wartości, które przyczyniają się do wzajemnego postrzegania odmienności z różnymi tego skutkami" ${ }^{\text {. Po }}$ przełomie społeczno-politycznym w 1989 roku również wśród polskich mniejszości narodowych i etnicznych zaobserwować możemy wzrost liczby organizacji kulturalnych (edukacyjnych, religijnych, gromadzących materialne przejawy dziedzictwa kulturowego etc.), a także swoisty renesans tożsamości kulturowej (językowej, narodowej, regionalnej czy religijnej). W prezentowanym artykule pragnę skoncentrować się na procesie restauracji szkolnictwa religijnego polskich Żydów oraz skonfrontować jego współczesne formy z jakże bogatym tradycyjnym systemem dwustopniowego nauczania w chederach i jesziwach obo-

* Dr Joanna Cukras-Stelagowska jest adiunktem w Pracowni Teorii Wychowania na Wydziale Nauk Pedagogicznych UMK.

${ }^{1}$ M. Golka, Oblicza wielokulturowości, w: M. Kempny, A. Kapciak, S. Łodziński (red.), U progu wielokulturowości, Warszawa 1997, s. 55. 
wiązującym od XV wieku na ziemiach polskich, abstrahując przy tym do analizy istoty edukacji żydowskiej nakreślonej w Biblii.

\section{Chedery i akademie talmudyczne}

Od wieków dla żydowskiej rodziny najistotniejsze było wychowanie potomstwa w religii mojżeszowej. Duży wpływ wychowawczy miała matka, która przekazywała podstawowe zasady wiary oraz dbała o obchodzenie świąt religijnych w domu. Ponadto tradycja nakazywała, żeby dzieci uczono szacunku dla rodziców, starszych i uczonych ${ }^{2}$. Kodeks rabiniczny Szulchan Aruch obligował rodziców (szczególnie ojca) do zapoznania synów z Torq, a następnie posłania ich na naukę do nauczyciela lub zatrudnienie nauczyciela domowego ${ }^{3}$. Szczególne znaczenie przypisywano wychowaniu chłopców, ideałem większości rodziców był syn - rabin, znawca nauk judaistycznych. „Według talmudycznego traktatu Pirke(j) Awot (heb. Nauki Ojców) pięcioletnie dziecko powinno już uczyć się Pięcioksięgu, dziesięcioletnie - Miszny (Prawa Ustnego), trzynastoletnie wykonywać obowiązujące przykazania, piętnastoletnie uczyć się Talmudu, a osiemnastoletnie mogło się żenić". Życie we wspólnocie gminnej od każdego mężczyzny wymagało biegłej znajomości przepisów religijnych. Ich nauka rozpoczynała się już w 3-4 roku życia:

Żydzi od wieków mówili o sobie, że są narodem Księgi - Am Hasejfer. Nie tylko dlatego, że posiadali na zwojach spisaną Torę, Księgę, jak wierzyli, zawierającą od Boga pochodzące zasady i przykazania swej religii, ale również dlatego, że posiadali znajomość czytania i pisania. Od wczesnej młodości wdrażano chłopcom czytanie i pamięciowe opanowanie Pięcioksięgu Mojżeszowego i pozostałych części żydowskiego Pisma Świętego. Tak powstał i z upływem wieków utrwalił się jako jeden z najstarszych na świecie system obowiązkowego powszechnego nauczania, realizujący zasadę jedności nauczania i religijnego wychowanias.

Tak duże zainteresowanie nauką we wspólnocie żydowskiej wynikało przede wszystkim z pobudek religijnych. Jednocześnie znajomość Talmudu i Tory, własnej historii i tradycji stanowiły warunek zachowania tożsamości i odrębności w chrześcijańskiej Europie .

${ }^{2}$ R. Renz, Wychowanie w rodzinie żydowskiej w Polsce międzywojennej, w: A. Bilewicz, S. Walasek (red.), Rola mniejszości narodowych w kulturze i oświacie polskiej w latach 1700 -1939, Wrocław 1998, s. 247.

${ }^{3}$ Por. J. Tomaszewski, Ojczyzna nie tylko Polaków. Mniejszości narodowe w Polsce w latach 1918-1939, Warszawa 1985, s. 112-113.

${ }^{4}$ Z. Borzymińska, Szkolnictwo żydowskie w Warszawie 1831-1870, Warszawa 1994, s. 65.

${ }^{5}$ Z. Hoffman, Szkolnictwo, w: M. Fuks, J. Hoffman, M. Horn, J. Tomaszewski (red.), Żydzi Polscy. Dzieje i kultura, Warszawa 1982, s. 84.

${ }^{6}$ A. Hertzberg, A. Hirt-Manheimer, Żydzi. Istota i charakter narodu, Warszawa 2001, s. 47-48. 
Tradycja przypisuje upowszechnienie obowiązku szkolnego wśród Żydów Szymonowi ben Szetach (uczonemu, którego życie przypada na pierwszą połowę I w. p.n.e.). Był on inicjatorem zakładania przy synagogach bądź w ich pobliżu szkół publicznych stopnia podstawowego zwanych be(j)t ha-sefer, w których uczyć się miały dzieci od 6-7 roku życia. Obok nich zaczęły także powstawać szkoły prywatne. Jak podaje Zofia Borzymińska: „Nauka w tych placówkach obejmowała czytanie i pisanie po hebrajsku oraz znajomość literatury klasycznej. Edukację rozpoczynano od czytania Księgi Kapłańskiej, po przerobieniu całego Pięcioksięgu przystępowano do odczytywania Proroków i Pism. Studiowanie Tanachu (Starego Testamentu) było podstawą nauki"’ . Wyższym stopniem edukacji były szkoły be(j)t ha-midrasz, w których młodzież uczyła się Prawa Pisanego i Prawa Ustnego. Część uczniów poświęcała się dalszym studiom, uzyskując na koniec tytuł rabiego ${ }^{8}$. W wiekach nowożytnych ukształtował się dwustopniowy model nauczania religijnego: w chederach i jesziwach. System ten dominował także na ziemiach polskich aż do okresu międzywojennego.

Najczęściej, gdy tylko dziecko nauczyło się dobrze chodzić i mówić, posyłano je na naukę do chederu, który miał przygotowywać do życia we wspólnocie religijnej. Chedery (z hebr. izba) to prywatne, religijne szkoły żydowskie, w których nauczano dzieci w wieku od 4, 5 do 12 lat. Zgodnie z tradycją naukę w nich podejmowali głównie chłopcy, zaś dziewczynki z bogatych rodzin kończyły naukę na pierwszym poziomie chederu lub pobierały edukację $\mathrm{w}$ domu u prywatnego korepetytora. Nauczyciel chederu (zwany mełamedem) oraz jego pomocnicy (belfrowie) zawierali z ojcem umowę na nauczanie syna, pobierali za nie wynagrodzenie. Rodzice mogli decydować, jakie przedmioty mają być wykładane w chederze 9 .

Pierwszy dwuletni kurs (dardeki) obejmował naukę czytania w języku hebrajskim opartą na Modlitewniku. Druga kategoria (trzyletnia) obejmowała pracę nad Torq z komentarzami Raszi Rabi Salamona Icchackiego, naukę etyki oraz zasad dobrego wychowania. Nauka Tory wyglądała w ten sposób, że mełamed czytał tekst oryginału, a następnie podawał thumaczenie danego fragmentu w języku żydowskim (opierał się na przekładzie wydanego na początku XVII wieku podręcznika Beer-Mosze). W trzeciej kategorii dziewięcioletni chłopcy zajmowali się przez kolejne dwa lata analizą Talmudu (również z komentarzami Raszi) ${ }^{10}$.

Nauka w chederze (lub talmud-torze) trwała do późnych godzin wieczornych (mniej więcej od godz. 9.00 do 21.00), szkółka ta pełniła zatem również funkcję ochronki. Dzieci dzielono na kilka grup, z których jedne uczyły się pod kierunkiem mełameda bądź belfra, inne w tym czasie bawiły się w ciszy. „Zaba-

${ }^{7}$ Z. Borzymińska, dz. cyt., s. 9.

${ }^{8}$ Tamże, s. $8-9$.

${ }^{9}$ Por. J. Hellwig, Edukacja młodzieży żydowskiej w XIX w. w Poznaniu, w: A. Bilewicz, S. Walasek (red.), dz. cyt., s. 120.

${ }^{10}$ Por. Z. Hoffman, Od chederu do jesziwy, „Kalendarz Żydowski” 1985/1986, s. 84. 
wa miała charakter dydaktyczny i polegała głównie na wynajdowaniu odpowiednich liter w tekstach Modlitewnika, Tory oraz Talmudu. Religijny charakter miały również święta obchodzone uroczyście $\mathrm{w}$ chederach, połączone $\mathrm{z}$ określonymi obrzędami"'11.

Zazwyczaj poziom nauczania oraz kwalifikacje nauczycieli religijnych były niskie. Bardziej światli Żydzi krytykowali tego typu szkoły, w szczególności za ich hermetyczny charakter i brak przedmiotów świeckich, przygotowujących do życia w szerszym społeczeństwie ${ }^{12}$.

Od wieków w chederach praktykowano nauczanie tradycyjną metodą pamięciowa, polegającą na tym, że nauczyciel odczytywał tekst, a uczniowie głośno za nim powtarzali tak długo, aż zapamiętali przerabiany fragment księgi ${ }^{13}$. Dopiero na trzecim poziomie (w ostatniej klasie), w którym zajmowano się wyłącznie studiami nad Talmudem, ,uczniowie nie byli już «prowadzeni za rękę», a mełamed był już dla nich raczej instruktorem i konsultantem. Nauka przestawała być dla nich sprawą «pamięciowego wkuwania» i rutyny, a stawała się kwestią intelektualnych zdolności”"14.

Krytyce poddawano również warunki, w jakich uczyły się dzieci. Szkoły mieściły się najczęściej w domu mełameda: „nauka odbywa się w izbie ciasnej, brudnej, pełnej błota i nieznośnego zaduchu. W tej samej izbie, w której odbywają się wykłady, gnieździ się także rodzina nauczyciela, rodzina zazwyczaj bardzo liczna"15. Zamożniejsza część Żydów z uwagi na niski poziom chederów wolała angażować dla swoich dzieci nauczycieli prywatnych, tzw. preceptorów ${ }^{16}$. Mimo krytyki (narastającej zwłaszcza w dobie Haskali) nie można zapomnieć, iż chedery pielęgnowały tożsamość religijną i narodową Żydów rozproszonych w diasporach, a przede wszystkim przyczyniły się do wysokiego poziomu alfabetyzacji tej społeczności ${ }^{17}$.

W wieku 13 lat chłopiec formalnie stawał się pełnoprawnym członkiem społeczności poprzez przejście obrzędu barmicwy. W tym wieku mógł również podjąć naukę na kolejnym etapie edukacji w jesziwach - akademiach talmudycznych, w których głównym przedmiotem nauczania był Talmud oraz jego komentarze. Biegła znajomość Talmudu była podstawowym warunkiem ukończenia z wynikiem pozytywnym akademii talmudycznej i otrzymania śmichy - czyli

${ }^{11}$ J. Hellwig, dz. cyt., s. 120.

${ }^{12}$ Por. tamże, s. $120-121$.

${ }_{13}$ Tamże, s. 66.

${ }^{14}$ Z. Hoffman, Od chederu, s. 84.

${ }^{15}$ Archiwum Państwowe w Kielcach, Urząd Wojewódzki Kielecki, sygn. 1690, Protokót z lustracji Gminy Wyznaniowej Żydowskiej w Kunowie z 18 sierpnia 1932 roku, cyt. za: R. Renz, dz. cyt., s. 249.

${ }^{16}$ Por. M. Woźniak, Żydowskie szkoty w II Rzeczpospolitej. Zarys problematyki, w: S. Walasek (red.), Studia o szkolnictwie i oświacie mniejszości narodowych w XIX i XX wieku, Wrocław 1994, s. 96.

${ }^{17}$ Por. Z. Borzymińska, dz. cyt., s. 70. 
certyfikatu rabinackiego ${ }^{18}$. System nauczania w jesziwach historyk Maurycy Horn charakteryzuje w następujący sposób:

Na czele akademii talmudycznej stali rabini, zwani rektorami. W jeszibotach panował na ogół sofistyczny system nauczania. Polegał na wyszukiwaniu istotnych lub pozornych sprzeczności , chilukim, po hebrajsku różnice” w Biblii lub Talmudzie i usuwaniu ich przy pomocy przesłanek zapożyczonych z dzieł literatury talmudycznej. Stosowano przy tym argumentację polegającą na wykorzystaniu wieloznaczności słów, stosowaniu trudnych do wykrycia nieścisłości, a nawet posługiwaniu się sofizmami. Metodę tę zwaną pilpulem ,pieprzem” krytykowali niektórzy światlejsi rabini ${ }^{19}$.

Chłopcy, którzy po ukończeniu chederu nie kontynuowali nauki w akademiach, lecz podejmowali pracę i zakładali rodzinę, mogli zgłębiać wiedzę religijną w domach nauki przy synagogach, tzw. bet-hamidraszach ${ }^{20}$. W praktyce wielu Żydów uczyło się przez całe życie, tak jak nakazywała im religia.

\section{Początki nauczania religijnego na ziemiach polskich}

Do XV wieku Polska pozostawała na uboczu głównych trendów żydowskiego życia intelektualnego. W tym czasie główne ośrodki myśli żydowskiej mieściły się w Hiszpanii, Francji, Włoszech i Niemczech oraz w Północnej Afryce (Egipcie, Maroku). Jednak narastające fale prześladowań w Europie Zachodniej wywołały migracje na wschód, sprowadzając na ziemie polskie dużą liczbę Żydów (zwłaszcza z Niemiec, Czech i Moraw oraz Ślasska). Podobnie jak to odbywało się w innych diasporach, również polscy Żydzi rozpoczęli budowę struktur społecznych, opierając się na zasadach religii mojżeszowej. Utworzono gminy - zwane kahałami, które rządziły się odrębnymi prawami od pozostałych stanów Rzeczpospolitej. Kahały miały swojego rabina, zarząd (seniorów, starszych kahalnych), własne sądownictwo oraz komisje i bractwa zajmujące się różnymi dziedzinami życia. Każda gmina posiadała synagogę, szkołę, szpital - przytułek, łaźnię rytualną i cmentarz ${ }^{21}$. Wszelkie regulacje prawne i społeczne wymagały głębokich studiów nad Pismami, dlatego też żydowscy uczeni, którzy osiedlili się w Polsce, rychło zaangażowali się w studiowanie, komentowanie, interpretację oraz nauczanie Talmudu².

${ }^{18}$ Por. J. Hellwig, dz. cyt., s. 121.

${ }^{19}$ M. Horn, Kultura żydowska w Polsce do końca XVIII wieku, w: M. Fuks, J. Hoffman, M. Horn, J. Tomaszewski (red.), dz. cyt., s. 28.

${ }^{20}$ Por. R. Renz, dz. cyt., s. 249.

${ }^{21}$ P. Fijałkowski, Dzieje Żydów w Polsce. Wybór tekstów źródłowych XI-XVIII wiek, Warszawa 1993 , s. 8.

${ }^{22}$ Por. R. Spira, Rabbis and jewish scholars in Poland in the 16th, 17th and 18th centuries, Bibliophilic edition 1985, s. 1-2. 
Pomiędzy XVI a XVIII wiekiem żydowski system edukacji w Polsce związany był wyłącznie z nauczaniem zasad judaizmu. Gminy utrzymywały szkoły zwane talmud-torami, do których uczęszczały biedniejsze dzieci, obok nich funkcjonowały prywatne chedery dla zamożniejszych Żydów ${ }^{23}$. Ponieważ edukacja na poziomie podstawowym była obowiązkowa, praktycznie nie istniało wśród Żydów zjawisko analfabetyzmu. Po ukończeniu szkółki religijnej bystrzejsi uczniowie wstępowali do jesziw - tzw. akademii talmudycznych.

Główne ośrodki żydowskiej myśli religijnej mieściły się w Poznaniu, Krakowie, Lublinie, a później również we Lwowie, Ostrowie, Wilnie i Grodnie. Działające $w$ tych miastach jesziwy $w$ swoich najlepszych latach funkcjonowania przyciagały wielu słuchaczy z całej Europy. Pierwsza akademia talmudyczna, ufundowana przez Mojżesza Mentza, powstała w XV wieku w Poznaniu. Słynna krakowska jesziwa utworzona przez Jakuba (zwanego później Jakubem Polakiem, autora metody pilpulistycznej) przeżywała swój złoty okres pod rządami Mojżesza Isserlesa (Remu), autora komentarza do dzieła Josefa Karo Szulchan Aruch, przystosowującego Talmud do tradycji Żydów wschodnioeuropejskich. Natomiast jesziwa lubelska największą sławą cieszyła się, gdy jej rektorem byli Salomon Szachna oraz Salomon Luria (przeciwnik scholastycznego pilpulu) ${ }^{24}$.

Siedemnastowieczny kronikarz Natan Hannower wspominał, że każda gmina żydowska w Rzeczpospolitej miała swoją jesziwę, a jej zwierzchnik opłacany był z funduszy publicznych. Do obowiązków gminy należało również utrzymanie studiującej w niej młodzieży. Według jego relacji, absolwenci jesziw cieszyli się wielkim poważaniem w społeczności żydowskiej.

Wiek XVI i pierwsza połowa XVII to wyjątkowy okres w historii rozwoju myśli religijnej dla polskich Żydów. Sytuacja zmieniała się w drugiej połowie XVII wieku, gdy wraz ze wzrostem nietolerancji religijnej oraz na skutek licznych wojen, jakie prowadziła Rzeczpospolita, wielu żydowskich uczonych wyjechało z Polski i osiedliło się z powrotem na Zachodzie ${ }^{25}$. Jak podaje M. Horn, zamknięto wówczas wiele polskich jesziw, które do niedawna cieszyły się uznaniem szeroko poza granicami kraju, zaczęły również podupadać chedery, pozbawione wykwalifikowanych nauczycieli ${ }^{26}$.

Rozwijająca się w drugiej połowie XIX wieku haskala, głosząca hasła rozwoju społecznego, którego orężem miała być przede wszystkim nauka i zbliżenie z kulturą narodową państw, w których dane było mieszkać Żydom, dała początki reformom szkolnictwa. Zdecydowana większość Żydów z Królestwa Polskiego pozostawała jednak wierna tradycyjnej edukacji religijnej - w drugiej połowie XIX wieku nadal 90\% dzieci wyznania mojżeszowego uczyło się w chederach ${ }^{27}$.

\footnotetext{
${ }^{23}$ Por. P. Fijałkowski, dz. cyt., s. 10.

${ }^{24}$ Por. R. Spira, dz. cyt., s. 2; oraz P. Fijałkowski, dz. cyt., s. 11.

${ }^{25}$ Por. R. Spira, dz. cyt., s. 3.

${ }^{26}$ M. Horn, dz. cyt., s. 28.

${ }^{27}$ Tamże, s. 33.
} 
Społeczność żydowska nie była jeszcze gotowa na gwałtowne zmiany w szkolnictwie, życie w diasporze w mniemaniu Żydów ortodoksyjnych wymagało odcięcia się od świeckiego modelu życia, od wszelkich pokus asymilacji. Zygmunt Hoffman wyznaje pogląd, iż

przyczyny niechęci do rządowych szkół żydowskich były podobne do tych, które towarzyszyły realizacji znacznie wcześniejszych edyktów oświatowych Józefa II w Galicji. Oświata świecka dekretowana odgórnie masom społecznie nie rozbudzonym, zamkniętym od wieków w kręgu średniowiecznej dogmatyki religijnej nie budziła zaufania. Natomiast ciężar utrzymywania tych szkół spadał na żydowskiego podatnika, chociaż nie uznawał je za szkoły żydowskie ${ }^{28}$.

Pod wpływem nowych prądów udało się powołać w 1826 roku Warszawską Szkołę Rabinów, tj. średnią szkołę religijną, która miała kształcić przyszłych rabinów oraz nauczycieli dla żydowskich szkół elementarnych, dodajmy - jedyną żydowską szkołę średnią na terenie Królestwa Kongresowego. Wykładano w niej przedmioty teologiczne (Biblię, Talmud, Misznę wg Majmonidesa, nauki moralne oparte na Biblii i Talmudzie, homiletykę) oraz gramatykę języka hebrajskiego i polskiego, historię powszechną i historię Polski, geografię, matematykę, prawodawstwo, języki obce: francuski, niemiecki i rosyjski. Przedmioty ogólne prowadzono w języku polskim ${ }^{29}$. W ciągu 37 lat funkcjonowania szkołę ukończyło 1200 uczniów, choć tylko pięciu absolwentów zostało rabinami, pozostali wybierali inne zawody (głównie pracowali jako nauczyciele w szkołach żydowskich oraz prawnicy i lekarze $)^{30}$.

Żydowskie odrodzenie przyczyniło się również do zmian w chederach, w których zaczęto wprowadzać przedmioty świeckie (m.in. języki obce i matematykę) ${ }^{31}$. Innowacje te były jedynie pierwszymi próbami reform szkółek religijnych. Haskala na ziemiach polskich nie miała bowiem tak dużej siły oddziaływania jak w Europie Zachodniej, a środowiska ortodoksyjne broniły się przed wprowadzeniem przedmiotów świeckich. Na większą skalę zaczęto usprawniać chedery dopiero w okresie międzywojennym.

${ }^{28}$ Z. Hoffman, Od chederu, s. 86.

${ }^{29}$ Por. B. Daniłowicz, Jutrzenka - tygodnik dla Izraelitów Polskich, w: S. Walasek (red.), Studia, s. 46.

${ }^{30}$ Por. M. Skowroński, Szkoła Rabinów w Warszawie (1826-1863). Jaki byt cel jej istnienia?, w: S. Walasek (red.), Wśród «swoich» $i$ «obcych». Rola edukacji w spoleczeństwach wielokulturowych Europy Środkowej (XVIII-XX wiek), Kraków 2006, s. 57.

${ }^{31}$ Por. Z. Borzymińska, Dzieje Żydów w Polsce. XIX wiek. Wybór tekstów źródtowych, Warszawa 1994, s. 69-70. 


\section{Szkolnictwo religijne w okresie dwudziestolecia międzywojennego}

W okresie międzywojennym dzieci żydowskie miały możliwość uczęszczania do szkół państwowych z polskim językiem wykładowym, ale prowadzących również naukę religii mojżeszowej (tzw. szabasówek) oraz do publicznych szkół powszechnych wielowyznaniowych z polskim językiem wykładowym. Mimo postulatów kół żydowskich nie udało się stworzyć publicznych szkół z żydowskim lub hebrajskim językiem nauczania. Drugi typ szkolnictwa miał charakter niepubliczny. Szkoły te tworzyły i prowadziły różne organizacje polityczne, religijne i kulturalno-oświatowe, które w okresie II Rzeczpospolitej miały możliwość swobodnego rozwoju. Funkcjonowało kilka typów takich szkół:

- religijne (chedery, talmud-tory, jesziboty [jesziwy] małe i wielkie);

- świeckie: 1) szkoły z językiem jidysz; 2) z językiem hebrajskim; 3) utrakwistyczne (z językiem polskim i hebrajskim; polskim i jidysz; rzadziej z jidysz i hebrajskim $)^{32}$.

W II Rzeczypospolitej nadal funkcjonowały prywatne szkoły religijne ${ }^{33}$. Szkołami tymi opiekowała się Centralna Organizacja Oświatowa „Chorew”, podległa „Związkowi Izraela - Agudzie” (ortodoksyjnej partii, której głównym celem było umocnienie wiary i utrzymanie tradycyjnego modelu życia, przy zachowaniu lojalności wobec państwa polskiego). Od 1902 roku Towarzystwo Szerzenia Oświaty Wśród Żydów zaczęło tworzyć chedery nowego rodzaju, w których wprowadzono podział na klasy, ustalono liczbe godzin lekcyjnych, wprowadzono nauczanie przedmiotów ogólnokształcących, starano się również o lepsze urządzenie klas szkolnych i o pomoce naukowe ${ }^{34}$. W obliczu wprowadzenia powszechnego obowiązku szkolnego (w 1919 roku) możliwość dalszego funkcjonowania chederów uzależniona została od uznania przez władze, czy w konkretnej szkole możliwa jest realizacja obowiązku szkolnego. W sytuacji realnego zagrożenia zamykania placówek „Chorew” rozpoczęła akcję propagującą reformę wśród żydowskiej społeczności. W chederach nowego typu na przedmioty religijne przeznaczono od 27 do 37 godzin tygodniowo, zaś na przedmioty

${ }^{32}$ Por. H. Chałupczak, T. Browarek, Mniejszości narodowe w Polsce 1918-1995, Lublin 1998, s. 177.

${ }^{33}$ Według danych z 1934-35 roku do szkół publicznych (łącznie podstawowych, średnich, zawodowych, specjalnych, wyższych) uczęszczało ponad 471 tysięcy dzieci i młodzieży żydowskiej. Zaś do szkół tworzonych przez mniejszość żydowską ponad 244,4 tysiące (w tym ponad połowa do szkół religijnych: prowadzonych przez organizację Chorew uczęszczało 80 tysięcy, do żeńskich chederów „Bejt Jakow” 20 tysięcy dziewcząt, natomiast do chederów i gimnazjów prywatnych ponad 48 tysięcy dzieci żydowskich). Por. R. Żebrowski, Dzieje Żydów w Polsce. 1918-1939. Wybór tekstów źródłowych, Warszawa 1993, s. 110.

${ }^{34}$ Por. S. Mauersberg, Szkolnictwo powszechne dla mniejszości narodowych w Polsce $w$ latach 1918-1939, Wrocław-Warszawa-Kraków 1968, s. 172. 
świeckie przeciętnie 12 godzin. Nauka trwała w nich 8 lat (począwszy od 6 roku życia dziecka) ${ }^{35}$.

Zwolnienie uczniów chederów reformowanych z obowiązku nauki w szkołach publicznych oficjalnie nastapiło w 1922 roku, jednak w dalszych latach nadal było uzależnione od realizacji szeregu wymogów organizacyjnych. Wyznaczono m.in. liczbę godzin przeznaczonych na naukę przedmiotów świeckich. Nauczyciele tych przedmiotów musieli posiadać odpowiednie kwalifikacje zawodowe ${ }^{36}$. Przeważająca liczba szkół religijnych nie spełniała wymogów, a w obawie przed restrykcjami uchylała się od rejestracji. Zamykane dla przykładu chedery wywoływały wprawdzie chwilowe zamieszanie w środowisku, ale w ostatecznym rozrachunku spychało to jedynie szkoły do działalności bardziej zakonspirowanej. Chedery zreformowane funkcjonowały przede wszystkim w większych ośrodkach miejskich. Zaledwie 1/4 uczniów chederów społecznych i prywatnych była zwolniona z obowiązku szkolnego w szkołach publicznych ${ }^{37}$.

$\mathrm{Na}$ poziomie szkoły średniej nauczanie religijne obejmowało wyłącznie chłopców. Realizowano je w tzw. jeszybotach małych, w których wykładano Talmud. S. Chmielewski podawał, że w 1936 roku istniało w Polsce 147 jeszybotów tego typu z liczbą 18800 słuchaczy. Funkcjonowały także jeszyboty wielkie w których kształcono rabinów, sędziów religijnych, nauczycieli religii, kierowników szkół religijnych oraz talmudystów ${ }^{38}$. Do najbardziej znanych należały jesziwy w Mirze oraz Lublinie. Uczelnie talmudyczne skupione były głównie w Polsce centralnej i wschodniej. Ich siedziby mieściły się najczęściej w małych, prowincjonalnych miasteczkach: Radzyniu, Pabianicach, Otwocku, Łomży, Klecku, Bobowej, Zambrowie, Słucku, Słonimimiu, Baranowiczach, Kobryniu, Ostrogu, Raduniu, Równem, Kamieńcu, Wołożynie, Piaskach, Międzyrzecu, Korcu; oraz w większych ośrodkach: Białymstoku, Nowogródku, Brześciu Litewskim, Grodnie, Łucku, wyjątkowo w wielkomiejskich: Krakowie, Warszawie, Wilnie ${ }^{39}$.

W 1930 roku utworzono dzięki ogromnemu zaangażowaniu rabina Majera Szapira znaną w całym kraju oraz szeroko poza jego granicami szkołę rabinów - Uczelnie Mędrców Lublina (Jeszywas Chachmej Lublin). Uczelnia przetrwała do wybuchu wojny, kiedy to jej siedziba została zamieniona na szpital wojskowy, a bogaty księgozbiór zniszczony. Lubelską jesziwą kierowało Kolegium Rabinów, składające się z najwybitniejszych znawców nauki talmudycznej w kraju, które wybierało spośród swoich członków rektora, a ten z kolei z pomocą rady pedagogicznej przeprowadzał egzaminy wstępne i układał programy zajęć.

${ }^{35}$ Tamże.

${ }^{36}$ Por. S. Mauersberg, dz. cyt., s. 164.

${ }^{37}$ Por. S. Chmielewski, Stan szkolnictwa wśród Żydów w Polsce, „Sprawy Narodowościowe” 1 (1937), cyt. za: S. Mauersberg, dz. cyt., s. 174-175.

${ }^{38}$ Tamże, s. 176.

${ }^{39}$ Por. J. Tomaszewski, Najnowsze dzieje Żydów w Polsce, Warszawa 1993, s. 249. 
Wpływy czerpano z dotacji, darowizn, subsydiów gmin żydowskich, fundacji i zbiórek ${ }^{40}$.

Studia talmudyczne trwały w niej cały dzień, przerywane jedynie na modły oraz spożywanie posiłków. Godziny wieczorne przeznaczano natomiast na samodzielną pracę studentów w bibliotece oraz realizację projektu naukowego uczelni - tworzenia encyklopedii talmudycznej. Każdego dnia studenci uczestniczyli w wykładach rektora oraz samodzielnie studiowali pensum talmudyczne połączone z lekturą komentarzy i fragmentami kodeksu Szulchan Aruch oraz teksty dotyczące problematyki etycznej. Sięgano także po teksty komentarzy rektorów lubelskiego gimnazjum talmudycznego w XVI wieku ${ }^{41}$.

Językiem wykładowym był hebrajski, zaś w kontaktach codziennych porozumiewano się w jidysz. W uczelni skupiono się wyłącznie na nauczaniu religijnym. Jej wieloletni dyrektor Majer Szapir z obawy przed wpływami świeckimi zdecydował się nie wprowadzać zajęć z przedmiotów ogólnokształcących. Podjął taką decyzję, mimo że absolwenci Jesziwy, którzy chcieli zostać rabinami, musieli zdawać państwowy egzamin z przedmiotów niereligijnych ${ }^{42}$.

Wraz ze śmiercią założyciela Jesziwy (1933 r.) skończył się złoty okres jej działalności, kolejne lata jej funkcjonowania przebiegły pod znakiem rywalizacji o stanowisko rektora. Wojna położyła kres działalności Jesziwy, niemniej jednak, jak podaje The Oxford Dictionary of the Jewish Religion, posłużyła ona za model dla wielu akademii talmudycznych na świecie (jesziwy - wzorowane i nazwane na jej cześć Jesziwas Chachmej Lublin - powstały m.in. w Tel Awiwie i Detroit) ${ }^{43}$.

W dwudziestoleciu międzywojennym novum stanowiła edukacja religijna dla dziewcząt, które zyskały możliwość nauki w chederach niższego stopnia, tworzonych specjalnie dla nich. Potrzeba kształcenia kobiet w duchu religijnym została dostrzeżona w środowisku ortodoksyjnym w momencie, gdy dziewczęta żydowskie pobierały naukę głównie w szkołach świeckich, gdzie opanował je „głód doczesności, udziału w cywilizacji ogólnej [...], nęci ją blichtr kultury europejskiej" ${ }^{44}$. Inicjatorką kształcenia kobiet była Sara Szenirer, która w 1917 roku w Krakowie założyła pierwszą tego typu szkołę. Dziewczęta uczyły się w niej czytania i pisania w języku hebrajskim i żydowskim. Dzięki zaangażowaniu Szenirer w 1924 roku działało 19 szkół, a naukę w nich pobierało 2 tys. dziewczą ${ }^{45}$. Palcówki te podlegały organizacji „Bejs Jakow” (z ramienia partii Aguda), stawiały sobie za cel wychowanie dziewcząt w duchu religijnym i narodowym.

${ }^{40}$ H. Raczek, Działalność oświatowa społeczności żydowskiej na Lubelszczyźnie, w: Bilewicz i S. Walasek (red.), dz. cyt., s. 285-286.

${ }^{41}$ Por. K. Zieliński, N. Zielińska, Jesziwas Chachmej Lublin, Lublin 2003, s. 133.

${ }^{42}$ Tamże, s. 134-135.

${ }^{43}$ Tamże, s. 173-174.

${ }^{44}$ H.Seidman, Renesans religijny kobiety żydowskiej, Sara Szenirer - człowiek i dzieło (1936 r.), cyt. za: R. Żebrowski, dz. cyt., s. 99.

${ }^{45}$ Por. M. Eisenstein, Jewish Schools in Poland 1919-1939. Their Philosophy and Development, New York 1950, s. 86. 
Obok sieci szkół religijnych powstała cała gama szkół świeckich, stworzona przez różne żydowskie ugrupowania polityczne. W pierwszej połowie latach dwudziestych wśród prywatnych szkół żydowskich prym wiodły szkoły z językiem wykładowym jidysz, natomiast $\mathrm{w}$ drugiej połowie przewagę zdobyło szkolnictwo hebrajskie, a na trzecim miejscu plasowały się szkoły dwujęzyczne z polskim i żydowskim językiem nauczania. Pod koniec lat trzydziestych znowu zaszły zmiany: na czoło wysunęły się szkoły utrakwistyczne (polsko-żydowskie lub polsko-hebrajskie), co wiązało się ze wzrostem znaczenia języka polskiego dla edukacji i przyszłej kariery zawodowej młodych Żydów. Drugą pozycję utrzymały szkoły z językiem hebrajskim ${ }^{46}$.

\section{Współczesne transformacje żydowskiego systemu edukacji religijnej}

Po II wojnie światowej skoncentrowano się na odtworzeniu szkół niższego stopnia, dopiero po napływie repatriantów z ZSRR (wśród których było sporo religijnej młodzieży) zaczęto organizować także jesziwy. W 1947 roku działało 36 chederów z liczbą uczniów 1100. Działały jesziboty w Krakowie, Wrocławiu i Szczecinie oraz Wyższa Szkoła Rabinacka Netzach Israel w Łodzi, w której studiowało około 100 osób $^{47}$. Jednak już w 1949 roku zlikwidowano akademie talmudyczne ze względu na brak chętnych i trudności czynione kongregacjom wyznaniowym, choć nadal działały nieliczne talmud-tory ${ }^{48}$.

W roku 1961 w Polsce istniało już tylko 9 szkół państwowych z językiem jidysz, do których uczęszczało ponad tysiąc uczniów. Ostatnie 4 żydowskie szkoły podstawowe w Łodzi, Szczecinie, Wrocławiu i Wałbrzychu oraz 3 licea ogólnokształcące w Legnicy, Łodzi i Wrocławiu zostały zamknięte w 1968 roku, po Wydarzeniach Marcowych i przymusowej emigracji Żydów ${ }^{49}$. Szkolnictwo żydowskie przestało funkcjonować aż do roku 1994, kiedy to Fundacja Ronalda Laudera powołała pierwszą niepubliczną szkołę żydowską w Warszawie. Cztery lata później powstała we Wrocławiu Szkoła Podstawowa Lauder Etz-Chaim. W statutach obu zespołów za jeden z najważniejszych celów uznano rozwijanie tożsamości żydowskiej poprzez naukę kultury i historii żydowskiej oraz języka hebrajskiego. Są to szkoły świeckie - utworzone z inicjatywy grupy warszawskiej i wrocławskiej inteligencji żydowskiej, wspierane przez żydowską fundację, do których pierwszeństwo w przyjmowaniu mają dzieci żydowskie. Jak dotąd, są to jedyne szkoły dla mniejszość żydowskiej w Polsce.

${ }^{46}$ Por. S. Mauersberg, dz. cyt.,s. 167-170.

${ }^{47}$ A. Cała, H. Datner-Śpiewak, Dzieje Żydów w Polsce. 1944-1968. Teksty źródłowe, Warszawa 1997, s. 224.

${ }^{48} \mathrm{~J}$. Adelson, $W$ Polsce zwanej ludowa, w: J. Tomaszewski (red.), Najnowsze dzieje Żydów w Polsce, Warszawa 1993, s. 465.

${ }^{49}$ Por. H. Chałupczak, T. Browarek, dz. cyt., s. 184. 
Od kilku lat młodzi członkowie społeczności żydowskiej mają również do dyspozycji bogaty i zróżnicowany wachlarz nieformalnej edukacji. Najwięcej zajęć prowadzą najprężniej działające gminy - w Warszawie, Łodzi, Wrocławiu i Krakowie. W dużych ośrodkach najmłodsze pokolenie polskich Żydów może swobodnie korzystać z kursów języka hebrajskiego (a w Warszawie również jidysz), uczestniczyć w zajęcia na temat kultury i historii żydowskiej, w obchodach świąt w gminie, brać udział w letnich obozach organizowanych przez Fundację Laudera lub Joint. W mniejszych gminach (w Bielsku-Białej, Szczecinie, Katowicach, Legnicy) oraz w filiach gmin dzieje się dużo, jednak są to projekty przeznaczone dla osób starszych. Jest to związane to z brakiem dostatecznej liczby młodych ludzi, którzy wyjeżdżają na studia do większych miast i tam integrują się ze środowiskiem żydowskim. Niestety, młodsze dzieci mieszkające na terenach filii żydowskich gmin zmuszone są dojeżdżać niekiedy kilkaset kilometrów na zajęcia do szkół niedzielnych, znajdujących się wyłącznie przy większych gminach. Mają one również trudniejszy dostęp do religijnych form edukacji na miejscu (na przykład dzieci z Gdańska nie mogą przystapić w swojej filii do barmicwy, gdyż nie posiada ona rabina).

Edukacja nieformalna ma „bardziej żydowski” charakter - inaczej bowiem niż w szkołach lauderowskich, jej twórcami i odbiorcami są osoby posiadające żydowskie korzenie. Sama natura edukacji nieformalnej wskazuje na ciekawsze i nieskrępowane wymogami oceniania formy prezentacji kultury żydowskiej. W takich przyjaznych mikrogrupach młodzi ludzie odnajdują pozytywne wzmocnienie własnej, dopiero co krystalizującej się, tożsamości. Przekaz wartości i postaw może się tutaj realizować spontanicznie, bez odgórnych nakazów i sankcji ${ }^{50}$. Propozycje żydowskich gmin wyznaniowych stanowią często uzupełnienie świeckiej edukacji proponowanej przez szkoły lauderowskie (przygminne szkółki i kluby młodzieżowe) bądź jej alternatywę (studia talmudyczne), zaś w miastach, w których mimo dużej liczby Żydów nie powstały szkoły Fundacji Laudera - zastępują formalną edukację.

W ciągu kilku ostatnich lat pojawiła się w Polsce niezwykle interesująca forma edukacji nieformalnej, przeznaczonej dla najmłodszych dzieci. W chwili obecnej działa pięć szkółek niedzielnych, które - jak zdawać by się mogło - nawiązywać będą do tradycji chederów. Przegląd ich oferty edukacyjnej oraz rozmowy z wychowawcami pokazały jednak, że nie są to typowe szkółki religijne, a ich charakter w znacznej mierze uzależniony jest od prowadzących zajęcia oraz gminy, przy której działają. Szkółki te mają mniej lub bardziej świecki charakter, nie prowadzą nauki religii mojżeszowej, choć ich program w znacznej mierze dotyczy judaizmu (jego zasad, nurtów, kalendarza świąt) oraz tradycyjnych elementów żydowskich (we wszystkich szkółkach wspólnie celebrowane są święta i szabas, przygotowywane koszerne posiłki). Koordynator szkółki warszawskiej wyjaśnia jej założenia w następujący sposób:

${ }^{50}$ Por. M. Jędrzejewski, Młodzież a subkultury, Warszawa 1999, s. 49. 
Nie jest to cheder, w której dzieci siedzą i czytają parsze, jest to raczej słynne informal education. Robimy dużo rzeczy, które mają być frajdą dla dzieci, a nie tylko edukacją [...]. Ogólnie staramy się, aby w zajęciach uczestniczyli głównie Żydzi, bo to jest szkółka żydowska, ale zazwyczaj jak ktoś przyjdzie z zewnątrz (taka jest moja polityka, z którą szefowie się zwykle zgadzają), jeśli na przykład któryś z naszych uczestników chce przyprowadzić dwóch polskich kolegów, bo opowiada im jak fajnie jest w klubie, to zawsze chętnie ich zapraszamy ${ }^{51}$.

Szkółki: łódzka, warszawska, wrocławska i krakowska ściśle ze sobą współpracują w kwestiach merytorycznych i wymiany informacji, a uczący w nich madrichowie oraz dzieci spotykają się na organizowanych wspólnie corocznych letnich koloniach w atrakcyjnych zakatkach Polski. Wszystkie omówione w tym rozdziale szkółki borykają się z tym samym problemem - małą liczbą dzieci oraz regularnością ich uczęszczania na zajęcia, co dezorganizuje nieco zajęcia (zwłaszcza systematyczną naukę języka hebrajskiego).

Madrichowie tworzą własne programy edukacyjne (na bazie wiedzy merytorycznej i dydaktycznej zdobytej na kursach organizowanych przez Joint). Sa to bardzo ciekawe propozycje nauki poprzez zabawę, przystosowane do potrzeb małych dzieci. Cotygodniowe zajęcia zawsze uatrakcyjniane są tańcami, śpiewem, warsztatami plastycznymi, wycieczkami. Zajęcia podzielone są zazwyczaj na kilka bloków tematycznych:

jest język hebrajski na takim bardzo podstawowym poziomie, zabawy językowe, zajęcia plastyczne, zabawy ruchowe, które są zawsze powiązane z tematem żydowskim. Organizujemy także w każdą trzecią niedzielę miesiąca imprezę cykliczną i urządzamy święta - na przykład imprezę chanukową, ale bez modlitw, jeśli dzieci chcą się modlić, to idą do synagogi. Mówimy także o współczesnym Izraelu ${ }^{52}$.

Podczas jednych tylko zajęć, jakie miałam okazję obserwować w szkółce wrocławskiej, dzieci grały w grę planszową (przesuwanie się po polach możliwe było po udzieleniu poprawnej odpowiedzi na temat konkretnego wydarzenia z historii narodu żydowskiego), uczyły się hebrajskich określeń części ciała i ich demonstracji w ruchu, zapoznawały się z różnymi nurtami judaizmu w zabawie Kim Jestem? (dzieci musiały najpierw odnaleźć pochowane w całym pomieszczeniu kolorowe karteczki, a potem przeczytać opis sylwetki Żyda i odgadnąć, czy jest to chasyd, żyd ortodoksyjny, konserwatywny czy reformowany).

Przy Gminie Wyznaniowej Żydowskiej w Warszawie od dwóch lat działa (jedyna jak do tej pory) ortodoksyjna szkółka, do której w każdą niedzielę mogą uczęszczać zarówno chłopcy, jak i dziewczęta pochodzenia żydowskiego. Szkółka o nazwie „Cheder” zdecydowanie bardziej nawiązuje do tradycyjnych form

${ }^{51}$ Wywiad z warszawskim madrichem.

${ }^{52}$ Wywiad z wrocławską madrich. 
nauczania religijnego. Opiekunami i nauczycielami dzieci są rabini. Zajęcia odbywają się w języku polskim, z wyjątkiem nauki modlitw w języku hebrajskim. Dla młodszych dzieci przygotowano gry i zabawy. Wiktor Osiecki w „Warsaw Voice” pisze na temat działalności chederu: „Na lekcji dzieci i ich rodzice moga dowiedzieć się, dlaczego podczas Rosz Haszana czyta się w synagodze historię ofiarowania Icchaka, dlaczego tego dnia dmie się w specjalny róg barani (szofar), czemu je się wówczas jabłka w miodzie, głowę ryby i inne niezwykłe potrawy oraz dlaczego grzechy «wyrzuca się» do wody"53. Dla nieco starszych dzieci stworzono plan zajęć, który obejmuje naukę modlitw żydowskich, studium Tory (Parszat Ha-Szawua) oraz naukę praw i zwyczajów judaizmu ${ }^{54}$.

Do niedawna młodzież chcąca kontynuować naukę judaizmu zmuszona była do wyjazdów do Izraela bądź Stanów Zjednoczonych, teraz ma również możliwość korzystania z edukacji religijnej w naszym kraju. Od kilku lat organizowane jest w Krakowie nauczanie stricte religijne, w pierwszej od lat sześćdziesiątych szkole religijnej - Jesziwa Pardes Lauder. Pod kuratelą Fundacji Laudera naukę judaizmu koordynuje dyrektor programu religijnego w Polsce, rabin Sach Pacaric. Studia odbywają się w systemie stacjonarnym i „dochodzącym”. Do stałych wykładów otwartych należą: w środy (oprócz świąt): Rambam i Raszi, w czwartki (oprócz świąt): hebrajski dla początkujących, w piątki - po kolacji szabatowej - dwar Tora, Ramban, aktualne parsze. Do wykładów zamkniętych: w niedzielę: Talmud - Kiduszin - Gemara, w poniedziałek: Talmud - Kiduszin - Miszna, w czwartek: Raszi, w sobotę musar ${ }^{55}$.

Studia talmudyczne można również podjąć w Szomrej HaDat w Łodzi, której program obejmuje modlitwy i czytanie Tory, wykładnię praw religijnych, nauki mistrzów chasydyzmu, podstawy mistyki żydowskiej, a także projekcję filmów edukacyjnych. Koordynacją wykładów oraz ich prowadzeniem zajmuje się rabin Szymcha Keller, zajęcia odbywają się w łódzkiej synagodze w każdą środę $e^{56}$. W lutym 2007 roku uroczyście otwarto synagogę w Lublinie, w miejscu gdzie do 1937 roku działała słynna lubelska jesziwa. Społeczność żydowska ma nadzieję na rychłe, ponowne otwarcie Uczelni Mędrców Lublina (Jeszywas Chachmej Lublin).

W czerwcu 2008 roku odbyła się pierwsza w Polsce od czasów II wojny światowej uroczystość rozdania tzw. śmichy, uprawniającej do wykonywania zawodu rabina w warszawskiej jesziwie Chabad. Jak powiedział rabin Szalom Ber Stambler, dyrektor tej działającej od 2005 roku szkoły:

Zakończenie pierwszego od ponad 60 lat roku akademickiego w Jesziwie w Warszawie jest kamieniem milowym dla społeczności żydowskiej obecnej tak w Polsce, jak i na całym świecie. Daje bowiem świadectwo odradzającej się diaspory w Polsce

\footnotetext{
${ }^{53}$ www.wiktor.goglepages.com.

${ }^{54}$ Tamże.

${ }^{55}$ www.pardeslauder.pl.

${ }^{56}$ www.jewishlodz.org.pl/religia_jesziwa.
} 
- kraju o wspaniałych tradycjach myśli i wiary żydowskiej. Jesteśmy dumni z tego faktu tym bardziej, iż przed wojną polska Jesziwa była największą szkołą talmudyczną na świecie ${ }^{57}$.

Odradzające się szkolnictwo religijne dla dzieci i młodzieży dodaje wiary na odrestaurowanie wspólnocie ortodoksyjnej, wskazuje „nowe drogi tradycji” współczesnej, zróżnicowanej, w znacznej mierze zsekularyzowanej społeczności żydowskiej. To również niezwykle interesujące zjawisko edukacyjne, w szczególności szkółki niedzielne, w których to dzieci żydowskie mają okazję rozwijać żydowską tożsamość już na bardzo wczesnym etapie i nawiązywać więzi we własnej grupie rówieśniczej. Wielu zastępują one szkołę formalną (nie wszyscy mają możliwość nauki w niepublicznych szkołach Laudera w Warszawie i Wrocławiu), tworząc ważne środowisko wychowawcze, dając również asumpt do dalszego zgłębiania wiedzy religijnej. Na szczególną uwagę zasługuje także, wymagająca odrębnych badań monograficznych i biograficznych, odradzająca się edukacja religijna wyższego szczebla. Zważywszy na bogatą tradycję oraz rangę akademii talmudycznych funkcjonujących niegdyś na ziemiach polskich, obecne propozycje „studiów” mogą wydawać się młodym, religijnym Żydom zbyt nieformalne, selektywne, zlaicyzowane, jednakże teraz ważne jest przede wszystkim, iż nauczanie religii mojżeszowej znowu, po latach milczenia, może być kontynuowane, a jak głosi Talmud: „Ten, kto uczy swoje dzieci, uczy nie tylko swoje dzieci, ale dzieci ich dzieci i tak do końca pokoleń" (Talmud Kiddushin 30a).

\section{From cheder to jeshiva in Polish diaspora... - two-degree system of jewish religious schools and its contemporary transformations (Summary)}

This paper shortly summerizes the history of jewish religious education in Poland - from the beginning in the XV century on the Polish lands, its growth during the XIX period, its domination between First and Second World War and finally total destruction in 1968. It took 28 years before it was possible to open a Jewish secular elementary school in Warsaw (1996), thanks to the assistance from the Ronald Lauder Foundation. Four years later, on initiative of Jews in Wrocław the Lauder Etz-Chaim elementary school was founded in this city. Democratization of social life in Poland after 1989 contributed to the change in Jews attitudes to their national descent. For many, their 'Jewishness', which now can be spoken about openly, has become the object of profound interest, intellectual search or the way to stress one's individuality. As a result, we can also observe the process of rebuilding Jewish religious life and forming sunday's schools, cheders and "Talmud academies" at Jewish Community in Warsaw, Krakow, Lodz, Gdansk and Wrocław (rather as a part of informal education, non- orthodox, more or less religious and adapted to modern jewish life-style in European diaspora).

${ }^{57}$ Źródło: Biuro Prasowe Chabad Lubawicz w Polsce, cyt. za: www.jewish.org.pl. 